\title{
Welfare benefits and labour supply: a review of the empirical evidence
}

\author{
Peter Brosnan, Moira Wilson and Dio Wong*
}

Assertions about the impact of welfare benefits on labour supply have often been made in claims that the New Zealand benefit system is in need of reform. This paper provides a review of empirical evidence of the relationship between labour supply decisions and the level, duration and eligibility requirements of unemployment benefits and income support provisions such as the Domestic Purposes Benefit. No clear cut conclusions emerge from the literature. In general the empirical link between disincentives to work in the benefit system and actual work behaviour is either insignificant or not substantial in terms of total labour supply.

\section{Introduction}

In the drive to achieve a more efficient "restructured" economy and to lower inflation, the current government has consciously allowed the number of unemployed to rise, and has deliberately sought to drive down real wages and increase the number of workers receiving low pay. Yet at the same time there is pressure to dismantle or reduce welfare provisions for those who are unemployed or in need of income support. The reasoning is that state provision for these people reduces their incentive to provide for themselves; the "unemployment trap", or alternately the "poverty trap" is sprung. Beneficiaries, it is argued, are caught in unemployment or in low income by financial incentives to not work. As a result labour supply in the economy falls to sub-optimal levels and the drain on the state budget becomes intolerable. In its most extreme form, this analysis lays the responsibility for unemployment at the door of social welfare benefits which make idleness attractive in comparison to work.

In a recently released policy proposal, the New Zealand Business Roundtable asserts that: "Labour market and income support reforms are linked" (New Zealand Business Roundtable, 1988). The Roundtable attributes unemployment to rigidity in the structure of wages, and to disincentives brought about by the interplay between benefits, the minimum wage, and family support provisions. It recommends that the Unemployment

Victoria University of Wellington. This paper draws on a report prepared under research contract for the Department of Social Welfare. We would like to acknowledge financial assistance given by the Department and stress that the views expressed in this paper are those of the authors. We would also like to thank the Editor, the Referees and Bob Stephens for their helpful comments. 
Benefit is allowed to fall in relation to wages and is limited to a maximum of 60 or 70 percent of previous earnings. In addition, the Roundtable proposes lowering the income level at which the benefit is withdrawn and raising the rate of its withdrawal.

Roger Douglas, the recently deposed Minister of Finance, endorsed moves to reform the benefit system and called for a "meaningful gap" between the incomes of those on wages and those not employed to give the unemployed incentive to work (Evening Post 5.12.87). Opposition MP and spokesperson for finance, Ruth Richardson, also adheres to the view that disincentives for self provision in the current system should be reduced:

Growing dependency is ensured for the lifetime sometimes of groups, individuals and families because the tax rate at the margin when earned income replaces state benefits ... is so steep that it provides no incentive to forego state benefits fo the earned income and thus to get off the treadmill (Address to Wellington Women Lawyers, 27 October 1988).

In particular she assails the Domestic Purposes Benefit for providing incentives to welfare dependence:

people who sleep around careless of the consequences impose substantial costs leaving others to pick up the tab. We can't afford the human and financial costs of this sort of behaviour, yet we run ... welfare systems that "pay" people to behave in that way (address to the National Party Conference, 6 August 1988).

Underlying this apparently pervasive view of the need for reform is the assumption that labour supply is a function of benefit provision. Benefits are held to presen disincentives which individuals act upon - it is assumed that benefits reduce labour supply.

The purpose of this paper is to explore the empirical basis for this assumption. We review empirical studies conducted in New Zealand and overseas which test the strength of the relationship between benefits and labour supply. Clearly a host of social, economic cultural and institutional factors shape and constrain any individual's decisions about how much labour to supply, but what do we really know about the relationship between benefits and labour supply? What weight, if any, do individuals give to the alleged financial incentives and disincentives of social welfare provision? If individuals do respond, how large is the response? Are there other factors to consider? How do different types of individuals respond? And which aspects of benefit provision do individuals respond to? These are important questions in policy design.

If individuals do not act on supposed disincentives to work, a basic contradiction in government policy is revealed. Policies to restructure the economy and to lower inflation have increased the need for unemployment assistance and income support. In removing provision or reducing the terms of assistance in the name of labour supply, government would be abdicating responsibility for the consequences of its actions.

\section{What is labour supply?}

At the outset we need a definition of labour supply. Freeman (1979) conceptualises labour supply as comprising six elements which, taken together, define the total supply of paid human labour. They are:

(1) The size and composition of the population;

(2) The proportion of the population willing to work;

(3) The number of hours worked each week;

(4) The number of weeks worked compared to those spent out of paid employment, or on vacations or holidays;

(5) The intensity of work effort; and
(6) The education and training of the work force.

Social security programmes can, at least in the long run, impact on all of these elements. Empirical studies, however, tend to concentrate on only two dimensions of labour supply. The first dimension is the second element an - the dimensions of population willing to work, usually termed the participation rate. Labour market participants are employers, the self-employed, wage and salary earners, relatives assisting without pay in a business, and the un without pay in a business, and the unemployed, who are willing to work, and thus in the labour force, but unable to find employment. The decision as to whether to be in or out of the labour force, particularly in the case of the unemployed, may be conditioned by the availability and nature of benefit provision.

The second dimension is a combination of the third and fourth elements above - the number of hours worked each week and the number of weeks worked compared to those spent out of paid employment, or on vacations or holidays. This measure of labour supply is usually referred to in the literature reviewed as "work effort". We will call it work activity to avoid confusion with the intensity of work ((5) above). Work activity refers to participation in work itself, as opposed to participation in the labour force. It eflects the propensity of unemployed persons to enter employment and the hours of work supplied by those in employment. Again, such decisions may be conditioned by the level and nature of social security provisions. While the participation rate is a measure of potential labour supply, work activity relates to actual labour supply.

\section{Methods of analysis}

Empirical studies generally seek to establish a relationship between the existence and size of benefits and these two dimensions of labour supply. The key explanatory variable is usually the replacement rate - the extent to which the benefit compensates for lost or potential market wages. It is believed that people have an idea of the wage they are prepared to work for - they have a "reservation wage" below which they will not supply their labour. It is argued that higher benefit replacement rates raise people's reservation wages. In this way, it is hypothesised, more generous levels of benefit provision reduce labour supply and induce greater dependency on social welfare provision. In addition, it is hypothesised that high effective marginal tax rates imposed by the abatement of benefits with increasing income reduce work acitivity. Five main methods of analysis are used:

(1) Surveys of beneficiaries. These ask contingency questions of benefit recipients, questions such as: "if you were to receive \$X unemployment relief would remain unemployed?" The results of this kind of research have often you innaccurate and inconcluse and are considered less reliable han innaccurate and inconclusive and are considered less reliable than more sophisticated econometric work

(2) Time-series analyses. These use regression analysis of aggregate economic data to establish a relationship between indices of labour supply and changes in benefit provision over time. The problem with this type of study is that it proves difficult to control adequately for changes in general economic conditions and changes in the labour market which also impact on labour supply decisions.

(3) Cross-sectional studies. These are similar to time series analyses but usually take account of more variables. Predictive econometric models are constructed from examining patterns in participation and work activity across a sample of individuals with different benefit entitlements. The better studios a sample of individuals influence of factors such as health, age, sex, occupation, labour market conditions and potential wages.

(4) Longitudinal studies. These improve on cross-sectional studies by examining the same sample of individuals over time.

(5) Experimentation. This final, most expensive method, is the least used. Experimental studies provide different benefit levels to a subject group and to a 
control group of beneficiaries and analyse subsequent variations in labour supply decisions.

Research has tended to become very mathematical and heavily reliant on the results of regression analysis and other statistical procedures. Any statistical examination of data can only identify relationships of correlation. Results do not necessarily imply causality, although they are usually suggestive of such. Inevitably, the question arises as to whether such "mathematization" of what is essentially human and social behaviour is appropriate. The interaction between work disincentives of benefit programmes and other noneconomic determinants of labour supply is complex. Studies control for other mediating factors to varying degrees but more qualitative determinants of labour supply tend to be neglected in any quantitative analysis. The simplifying assumptions, and arbitrary (and often inaccurate) specification of variables required abstract from reality to the extent that the results of analysis often cannot be applied realistically. Furthermore, aggregation of individual observations for the purpose of analysis loses the essence of the relationship on an individual level. There is also a need for caution in viewing the results of studies which use reported labour market data. Louis et al. (1986) found a discrepancy of up to 20 percent when they compared survey data with data that had been independently followed up and checked. They suggested that this arose from distortions in the accuracy of responses, induced by financial incentives associated with false declaration.

In addition to the methodological problems of each individual study, results must be qualified by consideration of the efficacy of the key explanatory variable, the replacement rate of benefits to previous or potential income. Hillier (1985) notes that given a preexistent replacement rate, an increase in benefits proportional to a rise in earnings would leave the rate unchanged, but it is likely that individual preferences and behaviour will have varied. Hillier suggests including earnings and benefit levels as separate variables in any analysis. Harrison and Hart (1983) claim the relevant variable is the nominal gap between earnings and the benefit. But again it is possible for individual behaviour to change while the earnings gap remains constant. Additional problems arise in the specification of the replacement rate. Aggregate data requires some averaging which is problematic if not all individuals receive the same benefit level. The studies reviewed ten unemployed who are mainly unskilled and low to middle income earners. Cross sectional data provides a fairly accurate measure of the benefit entitlement of each individual, but potential earnings were often imputed from limited information such as the industry the individual had left when becoming unemployed.

These qualifications must be borne in mind when interpreting the results of empirical work. In this paper we review findings on the relationship between first, unemployment benefits and labour supply, and second, various forms of family income support, particularly provision for single parent families, and labour supply.

\section{Unemployment benefits and labour supply}

Underscoring recent empirical economic interest in the effects of unemployment benefits on the labour market is a fear that unemployment assistance causes higher unemployment than would otherwise be the case. According to orthodox economic theory, as we understand it, unemployment benefits have three possible effects on labour supply.

Work disincentive effects:

(1) The level of unemployment may increase if unemployed workers fall into the "unemployment trap"; workers may be induced to leave employment, and may have no incentive to re-enter employment if they perceive the gains to be made from returning to employment as insufficient to offset loss of the unemployment assistance, as well as additional costs of transporting themselves to and from work,
clothing themselves for work, and losing leisure time.

(2) The existence and level of benefits may also cause the duration of unemployment for any individual to increase. Without the financial incentive to return to work immediately, unemployed workers may choose to adopt more leisure time or spend more time searching for the right job rather than accepting the first offer.

The entitlement effect:

(3) In the United Kingdom, United States and Canada, eligibility and entitlement are largely determined by contributions to the social security system when in previous paid employment. In these countries, work disincentive effects may to some extent be offset by an increase in the number of people participating in the some exten be offset by an increase in the number of people participating in the labour force, or individuals increasing their work activity in order to meet minimum eligibility requirements for unemployment relief and to increase the size of their entitlement. In New Zealand, to be eligible for the Unemployment Benefit, applicants must be seeking work. Labour market participation, or potential labour supply, may be greater than otherwise; as a result of benefit provision non-participants may be induced to declare themselves in the labour force.
ind

Empirical investigations are grouped in this section according to the relationship each examines; the studies reviewed seek to ascertain the relationship to the relationship each benefits and (a) the rate of unemployment, (b) the durationship betwec participation rate.

(a) The rate of unemployment

A number of studies use time-series analysis to examine the relationship between the level of benefits relative to average income, and the aggregate unemployment United Kingdom, both the replacement rate and the unemploym since 1948, which provided support, in early studies, for the hypothesis that higher unemployment benefits induce unemployment. But in fhe 1970 the relatis that highe down; unemployment in while the replacement rate tended to fall. Further doubt was cast on the results of earlier studies when it was found that the outcome of time series analyses was sensitive to replacement rate specification; the choice of variables representing the level of benefits and measuring averification; the choice results (Hemming 1984, p.110).

Gregory and Paterson (1983) undertook the first Australian study of this kind. Working on data for the period 1970-1979 they found a significant astudy of this kind. level of benefit provision and the number of benefit recipients. Rather than raising the total number of unemployed, however, the increase in the number of beneficiaries
primarily occurred because of primarily occurred because of an increased propensity of the unemployed to take up benefits. Recognising that the measured impact of benefit levels shrank as a greater number of other explanatory variables were included in their regression, Gregory and Paterson concluded that in general, the response to benefit payment changes occurred within the total unemployment pool. The importance of other variables, particularly indicators of labour demand and other labour market conditions, is illuables, particularly that the major increase in Australian unemployment in $1982-83$, is illustrated by the fact that the major increase in Australian unemployment in 1982-83 occurred when the ratio of benefits to average weekly earnings was falling (Social Security Review (SSR) Issues Paper No. 4).

Of the three relevant studies of unemployment in New Zealand (Braae, 1978; Hicks, 1984; Hyslop, 1987), two use the time-series approach. Braae (1978) tested the hypothesis of American economists Grubel and Maki (1976) that a rising replacement rate induces unemployment. Controlling for changes in the state of the economy, changes in labour supply (such as the increased participation of women) and government work schemes and administrative changes, Braae found a positive relationship between the unemployment rate and replacement rate. This, however, was only 
statistically significantly different from zero in one of the tests used, and likely to be biased in the other. Furthermore, the period under consideration by Braae was 1954-55 to 1972-73, when unemployment was low - much lower than the consistently high rates of unemployment in the mid to late 1970 s and 1980s.

A second study was presented in Hicks' (1984) PhD thesis. Hicks tested the same hypothesis but considered the period 1960-81, controlled for more variables and improved on Braae's specification of the replacement rate. Braae had used the ratio of a married person's benefit to average weekly earnings but most of the unemployed were single. To correct for this, Hicks used the single person's rate. Hicks' results directly contradicted Braae's findings and ran counter to the outcome of Grubel and Maki's study of unemployment in the United States. Several reasons for the insensitivity of unemployment in New Zealand to changes in benefit levels were suggested. In contrast to the United States, New Zealand has a flat-rate system of unemployment compensation where the size of the benefit is not related to previous earnings or contributions. The effective replacement rate facing each individual is much lower and provides less inducement to leave unemployed and stay unemployed than in the United States. New Zealanders do not contribute directly to a social security fund and because there is no qualifying period of employment or minimum level of contributions, the benefit is seen as a handout, not compensation as of right. As such it carries a stigma which may discourage workers from quitting employment even when benefit levels rise, and may discourage the involuntarily unemployed from claiming benefits to which they are entitled. Finally, coverage in New Zealand is limited by the income test. Eligibility is determined on the basis of the income of both the claimant and their spouse, which effectively excludes most married women as they tend to be secondary income earners with lower market wages than men. Studies reviewed below indicate that women, in particular married women, have the most sensitive labour supply response to changes in benefit levels. Therefore those whose registered unemployment rate might react most to changes in the Unemployment Benefit are largely excluded from receiving the benefit in New Zealand.

A further set of studies use cross-sectional analysis to relate the probability of being unemployed to the replacement rate. Minford (1983) claims a strong relationship for the UK and predicts that a 1 percent increase in the level of unemployment assistance, holding wages constant, will increase the unemployment rate by 2.3-4.0 percent. He recommends cuts in the Unemployment Benefit which, he predicts, will lower the reservation wage below which unemployed workers are unwilling to supply their labour, and reduce unemployment in the UK by up to 1.7 million. His method and results are severely criticised by Nickell (1984), and Layard and Nickell (1986) find a much smalle relationship which explains only 0.4 percentage points of the rise in unemployment since the late 1950s. Atkinson and Micklewright (1985) survey several British studies of the relationship between Unemployment Benefit rates and incentives to work and conclude that there is no firm evidence of a measurably large disincentive effect.

The most recent and thorough empirical work on British unemployment provision is by Beenstock et al. (1987). They used 1978 and 1981 Family Expenditure Survey data, and controlled for variables such as the age of the household head, the number of dependents, whether the family had a mortgage or not, the level of household income if the head were unemployed, and the industry unemployment rate for the head. Beenstock $e t$ al. found that the probability of being unemployed is not greatly influenced by the level of benefits, and concluded that, at household level, labour supply incentives and disincentives of the tax benefit system do not affect labour supply decisions. They suggested that other factors such as demand for labour and social pressure to work, have a stronger influence.

Indeed a study of the Canadian labour market by Osberg et al. (1986) demonstrates that if demand side influences are controlled for on an individual basis, the generosity of the Unemployment Insurance system is not a statistically significant determinant of the probability of being unemployed. Osberg et al. analysed a data set that matched individual employee characteristics with detailed information about their respective employers. The variability of sales and hiring costs of a worker's employers were employers. The Unemployment Insurance entitlements in determining his or her probability of being
unemployed.

\section{(b) The duration of unemploymen}

Most studies of the relationship between unemployment provision and labour supply are concerned not with the impact of benefits on the flow of labour into unemployment, but with the relationship between benefits and the flow of labour out of unemployment. It is usually hypothesized that higher replacement rates for unemployment assistance reduce the incentive to return to work, which lowers the probability of leaving unemployment and extends the duration of unemployment spells. Concern about the of such behaviour has stimulated substantial research spells. Concern about the cost conducted in the United States up to the mid 1970s, Hamch interest. Reviewing research conducted in the United States up to the mid 1970s, Hamermesh (1977) estimated that general a 10 percentage point increase in the replacement rate leads to an increase in the duration of unemployment of about half a week on average wheads to an increase in the Danziger et al. (1981) makes a guestimate from Hamermesh's labour markets are tight. ment Insurance provision as a whole extends the duration of un synthesis that Unemployweeks per recipient.

Moffit (1985) has estimated that, for males, a 10 percent increase in Unemployment Insurance entitlement extends the duration of unemployment in Unemployment Terminations of unemployment spells were of un exhaustion point. Hamermesh $(1979,1980)$ and Burgess and Kingston (1981) also find evidence that the duration of benefit eligibility impacts on the length of unemployment Indeed, on a cross-country comparison, Layard (1986) observed that countries with indefinite duration of eligibility for unemployment assistance have more long-term unemployment than those that have an upper limit on duration. It must be recog-term however, that this is largely a reflection of varying benit. It must be recognised, differences in labour supply behaviour. In many OECD countries, and in the United States, longer term unemployed for whom Unemployment Insurance eligibility has been exhausted tend to be transferred into work schemes or onto other benefits. This has less relevance in New Zealand since the Unemployment Benefit may continue indefinitely provided the beneficiary satisfies certain requirements.

In Britain, Narandranathan et al. (1985) found that the effect of the Unemployment Benefit on unemployment duration is significantly different from zero. The size of the effect is most pronounced among teenage males and falls with increasing age. For long term unemployed the effect is reduced, and is only significant for teenage males. They related to the size of the re to support the view that the effect of benefits on duration is related to the size of the replacement rate for different individuals.

Why the labour supply behaviour of teenagers is the most sensitive to benefit provision is a question of some dissent in the literature. Nickell (1979) interprets his (1983) argues instead lines as reflecting a lack of job offers received by teenagers. Minford supply their labour is higher reservation wage below which teenagers are not prepared to supply their labour is higher than the wage typically offered to them by employers. But for this to hold in Minford's own study, most individuals would have to maintain reservation wages above the maximum wage offer in his sample, which is unlikely - 50 percent of his sample received benefits less than half of the average after tax wage, comparable to the income of the lowest paid 10 percent of manual workers and below average earnings for British teenagers. Hunter et al. (1986) report that, in fact, British teenagers' reservation wages are more likely to lie below the mean of likely job offers.

In general, the effect of unemployment assistance on unemployment duration is rathe modest and, with the exception of Narandranathan et al (1985), the statistical significance of results can be viewed as not particularly impressive (Atkinson, 1987, p.863). 
Atkinson et al. (1984) challenge even this limited empirical conclusion by demonstrating the size of the effect is sensitive to the method and the assumptions used in statistical efecticement rate analysis. By changing the benefit variables or excluding family circumstances and indices the choice of time period, and by including or excluding fame set to produce findings of of need, they proved that it is possible for the same data set to prodfect. There is, significant effects on unemployment duration, or, alternately, no effect. Ther beliefs" therefore, "substantial scope for the conclusions drawn to be influenced demonstrated that (Atkinson et al., 1984, p.25). Furthermore, Osberg et al. (1986) have demonstrability of the duration of an individual's unemployment spell, as well as their probability of becoming unemployed, is not affected by the level of Unemployment Insurance if becoming unemployed, is not and for their labour are included in the analysis.

Findings on the impact of unemployment provision on the probability of leaving

Findings on the impact of unemployment provision replacement rate will raise the unemployment are contradictory. In theory a high replacement rate likelihood of reservation wage of unemployment assistance recipients and lower the likelihe and the leaving unemployment. Blau and Robins (1986b) claim that the reservation wage and the leaving $\mathrm{job}$ acceptance for Unemployment Insurance recipients in the United States are rate non-recipients. Of a sample of significantly different for sell between married men and women who experienced at least on a benefit level that replaced 50 January 1979 and October 1980, they found that with a benefit level that replace recipients percent of previous wages, the reservation wage of Uner for females than that of nonwas 11 percent higher for males and 9 percent higher for femer recipients. The rate of job acceptanc the deficiencies mean that double counting of job offers may have occurred in construction of the data. Narandranathan et al. (1985) found that changes in benefit levels have no impact the deaving unemployment, except in the

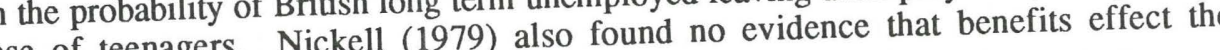
case of teenagers. Nickell (1979)

The limited empirical evidence avalable durot probability of leaving unemployment. Hicks (1984), duration of unemploym in addition to examining determinants ound a positive between the replacement rate and unemploym furation - it was relationship between the level of unemployment benefit payments and dur the average estimated that a 10 percent increase in the replacems estimad that a 10 percent increase in the replacement rale unemplo no raise aggregate unemployment by suggestin finding that higher replacement rato for a better job which that unemployed workers are encouraged to quit. Hicks offers them greater job security, and from which the concluded that benefit increases in New Zealand do not induce work to quil enploym so as to enjoy more leisure or a su so as to noy me already unemployed, which is ben time taken by those already unemployed, which is beneficial lowers the unemployment reduced

A more recent study of unemployment duration in New Zealand by Hyslop (1987) A mich uses micro data replacement rate and - March 1985. Again a positive relationship between the unemployment duration was found. Overall, however, unexplained variation institute a led both Hicks and Hyslop to conclude that this relationship did not constituslop's satisfactory explanation of unemployment duration in New Zealand. In addionent results were for a sample of unemployment beneficiaries who resumede the most likely leaving the register and thus ipso facto, were those unemployed who were leaving the to register do not resume employment but withdraw from the labour force. We the empirical evidence on the impact of unemployment assistance on the decision to participate in the labour force or to withdraw from participation.

(c) Labour force participation

Most of the studies reviewed so far assume that any increase in unemployment duration occurs at the expense of work activity; the general conclusion is that any findings of a relationship between benefit levels and unemployment illustrate the operation of work disincentive effects. But work disincentive effects apply only when someone who ordinarily would work is induced to remain unemployed. Some proportion of unemployed people, however, choose between unemployment and non-participation in the labour force. The link between unemployment duration and labour supply is not clear; a positive relationship between benefit levels and unemployment duration does not provide an appropriate measure of work disincentive effects because entitlement effects are also at work (Capen et al., 1985)

Solon (1979) suggests four ways in which entitlement effects of unemploymen assistance on labour force participation can operate. They are: (1) by encouraging continued job search by individuals who would otherwise become discouraged and quit looking for work; (2) by encouraging workers who are not really interested in work to pretend to be seeking work, in order to collect benefits; (3) by inducing individuals who would be disinterested in work to seriously conduct job search in accordance with Unemployment Insurance regulations; and (4) by inducing people who would be nonparticipants in the labour force to accept seasonal or temporary jobs in order to raise their entitlement.

Solon used data from a New York State Department of Labour Survey to examine the behaviour of Unemployment Insurance claimants. Analysis of the number of weeks recipients spent both in and out of employment and in and out of the work force showed that extending Unemployment Insurance eligibility for one week raised unemploymen duration by about one day on average. But it was estimated that two thirds of this increase was attributable to individuals choosing to delay leaving the work force. Extended unemployment duration occurred more at the expense of non-participation than at the expense of work activity. However, the focus period of the study was only six month and may not have been long enough to obtain reliable results. In addition, the sample comprised claimants who had exhausted regular benefits and was not representative of Unemployment Insurance claimants in general.

Nevertheless, similar findings resulted from a study by Barron and Mellow (1981). Using a national sample of unemployed workers from the United States Current Population Survey, Barron and Mellow estimated that, in any given month, 19 percent of recipients and 29 percent of non-recipients would find work, and that unemployment duration for Unemployment Insurance recipients was eight weeks longer than that for nonUnemployment Insurance recipients. But half the differential unemployment duration was attributed to recipients being more likely than non-recipients to stay in the work force in the face of unemployment.

Responsiveness, in terms of participation, to changes in unemployment assistance is greatest among women. Men tend to have a stronger attachment to the labour force with higher participation rates and longer work hours at all ages. Women's participation and work activity is more variable. Hamermesh (1979) examined, in addition to the work disincentive effect, the entitlement effect for white women aged between 30 and 54 . Unde the United States systems, individuals have the incentive to enter the work force or increase their work hours to meet the eligibility requirements or raise the level of insurance to which they are entitled. Using the Michigan Panel Study of Income Dynamics for 1971, Hamermesh discovered that women acted on these incentives; a 20 percent increase in statutory minimum weekly Unemployment Insurance entitlement was estimated to raise the participation rate of women by 1.1 percent and annual work time by 17 hours. Increased participation and work activity from entitlement effects almost 
exactly offset work disincentive effects. Hamermesh concluded that the net effect of Unemployment Insurance benefits on employment of prime age females was small.

In a second study, Hamermesh (1980) examined sample data for married women aged 25-54 from the 1970 United States Census. Hamermesh found that increased potential duration of benefits and easier eligibility requirements induced a greater average number of weeks to be worked by women. Women who worked only part of the year in seasonal or temporary work increased their work activity to become eligible for benefits the rest of the year. Women responded primarily to the terms of eligibility. The level of benefits had only a slight effect on labour supply behaviour.

New Zealanders with benefit entitlement (i.e. single people and persons without a primary income earner spouse) need only register as being unemployed and seeking work to qualify for the Unemployment Benefit. This provides incentive for non-participants to declare themselves in the labour force. Conversely, just as a proportion of unemployment beneficiaries may be disguised non-labour market participants, many women outside the workforce may represent disguised unemployed because they have no incentive to register as labour market participants out of work. The Household Labour Force Survey reports that the numbers in this latter category are substantial (Household Labour Force Survey; Table 6.2). Similarly administrative procedures for other benefits impact upon the measured incidence of unemployment and non-participation. Brosnan (1987) argues that much of the increase in usage of the Invalid's Benefit in New Zealand since the early 1970s represents a disguised increase in unemployment. Disabled workers are at the end of the queue for jobs in order of increasing disability. Rising unemployment means that even those with minor disabilities have difficulties finding work. Of the assistance options for disabled unemployed, the Invalids Benefit is more attractive financially than the Unemployment Benefit and is less subject to medical review than the Sickness Benefit. In addition, a change in administrative policy to transfer long term unemployed off the Unemployment Benefit in 1972-73 marked the beginning of a steep upward trend in Invalid's Benefit numbers which has continued throughout the 1970s and 1980s with worsening unemployment.

In Australia too, despite incentives for non-participants to disguise themselves as unemployed in order to collect the Unemployment Benefit, it would appear that a much greater problem is disguised unemployment. Stricker and Sheehan (1981) compared recent changes in participation rates with the long run trend and estimated that recorded unemployment of 374000 in 1980 was cushioned by the withdrawal of 340000 hidden unemployed from the labour force, mainly males over 55 and married women. The implication for the welfare budget was, therefore, not limited to a rise in demand fo unemployment assistance. The recession also induced rises in usage of service, invalid and age pensions, and to a lesser extent the Widows Pension and Supporting Parents Benefit. The low level of the Unemployment Benefit relative to these alternative forms of income support, and the general ineligibility of married women for unemployment relief had, in this case, the effect of reducing potential labour supply as measured by the participation rate.

(d) Unemployment benefits and labour supply: a summary

There is no consistent evidence that rising replacement rates of unemployment assistance induce more people into unemployment, or raise the probability of being unemployed. It is generally found that once in unemployment the existence, level and terms of unemployment assistance has an impact on the duration of unemployment spells, though there is no conclusive empirical evidence of an impact on the probability of leaving unemployment. The effect of benefit provision on unemployment duration is not necessarily indicative of substantial labour supply disincentive effects. First, the effect found is generally small in relation to total labour supply and its size and significance is sensitive to the specification variables and to the inclusion of variables reflecting demand side influences. Second, longer duration may facilitate a more extensive job search and reduce the rate of frictional unemployment and increase work activity in the long run. Third, longer duration is not necessarily at the expense of work activity. A significant proportion of those receiving unemployment assistance would be non-participants in the absence of assistance. For these people, the Unemployment Benefit has no impact on absence of assistance. For these people, the Unemployment Benefit has no impact on
work activity. Finally, under an unemployment insurance system, unemployment provision can have an offsetting effect of increasing the work activity of those particularly women, who want to become eligible for benefits or rise activity

\section{Family income support and labour supply}

Family income support payments take various forms. They supplement family income when it falls below a proscribed level. This level is often adjusted relative to family status, family size, and other indicators of need. Cash income supplements may be augmented by benefits in kind such as food stamps, medical aid and housing subsidies. The debate surrounding family income support programmes is concerned with what is termed the "poverty trap". There is a fear that, although family income support benefits generally do not provide for a standard of living beyond the poverty level, increasing them will reduce further any incentive for people to work to raise themselves out of poverty. In theory, a high replacement rate and high effective marginal tax rates imposed by the reduction of support as income increases, discourage labour market participation and work activity and induce long-term reliance on benefits.

The relationship between the form of provision and indices of labour supply has only been tested empirically overseas. Findings of this work are reviewed below. We then turn to more suggestive and less empirically conclusive findings for New Zealand and Australia.

\section{(a) Empirical findings}

Beenstock et al. (1987) provide an up-to-date and comprehensive investigation of the impact of disincentives in the British tax-transfer system on work activity. They constructed profiles of the incentives and disincentives faced by different types of worke the effective marginal tax rates imposed by the level of income support and its removal with increasing income, together with the income tax rate, varies with income, housing tenure status, family size and family status. They then compared the expected distribution of unemployment and work activity that would occur if individuals made rations according to the incentives they faced, with the actual distribution of unemployment and Expenditure Surveys. Finding no clear evidence that the 1978 and 1981 British Family Expenditure Surveys. Finding no clear evidence that people's work patterns are influenced by the tax-transfer system, Beenstock et al. concluded that individuals do not, or canno espond to labour supply incentives and disincentives.

These findings relate only to household heads who were predominantly male, although of the few solo mothers in the 1978 sample, a number chose to work hours which would have implied 100 percent effective marginal tax rates. While acknowledging several shortcomings with their analysis, ${ }^{1}$ Beenstock et al. raise several important possible explanations for their findings. First, the interplay of taxes and benefits, and their impact on net income, is complex. The assumption that individuals understand and act upon them may be unrealistic. Alternatively, other considerations such as social status, stimulation and self-worth may be more important than financial incentives in decisions

Beenstock et al. (1987) conceed that they did not control for interactions between leisure preferences and family status, housing tenure and earnings. They ignored the level of secondary income earner wages and also may have inappropriately imputed wage rates for the unemployed. Finally, the Chi-square test has been proved to be a blunt statistical instrument. 
about whether to work and how much to work. Finally, individuals may be unable to achieve their desired mix of hours and earnings. The majority of workers have little choice over whether or when they work, and are constrained to choosing between choice over whether or when they work, and are const
unemployment or non-participation, and a 40 hour week.

The main family income support programme in the United States is Aid to Families
. with Dependent Children (AFDC), which guarantees a specified level of assistance to families with low or zero income, and proportionately lower benefits as income increases. Families headed by solo mothers constitute a large proportion of AFDC recipients, and empirical work on family income support is concerned primarily with the labour supply response of wOm. response of women. Several studies seck to establish relationships bety provision and female labour force participation and work activity. Garfinkel and Orr (1974), Williams (1975) and Saks (1975) examined cross-sectional data for female AFDC recipients in the late $1960 \mathrm{~s}$. In response to a $\$ 500$ increase in the annual income guarantee, Garfinkel and Orr estimated a resultant 2.4 percent reduction in the rate of employment of recipients, and Williams and Saks predicted a drop in participation rates of recipients of 5.8 percent and 1.7 percent respectively. Raising the rate of benefit abatement by 10 percent was predicted by Garfinkel and Orr to lower employment rates by 1.4 percent, while Williams estimated a 2.1 percent fall in participation rates. The direction of the labour supply responses found in these studies is consistent with the operation of disincentive effects of the sort predicted by conventional economic theory. The size of the effects is not clear but appears small. The effect of changes in eligibility was not explored

Of five studies (Masters and Garfinkel, 1977; Levy, 1979; Barr and Hall, 1981; Hausman, 1981; Moffitt, 1980) analysing the economic behaviour of both AFDC recipient and non-recipient female heads of families, only one (Masters and Garfinkel, 1977) failed to find any effect on labour supply. Levy (1979), examined longitudinal Panel Study of Income Dynamics (PSID) data from 1968, and found that higher levels of guaranteed income reduced the supply of work, but that higher rates of benefit abatement actually increased work activity. Barr and Hall (1981), using a measure of welfare dependency as a proxy for labour supply, found evidence of work disincentive and incentive effects consistent with Levy's results. However Hausman's (1981) analysis of the 1975 PSID resulted in the observation of large negative impacts on hours worked from both the level of income guarantee and the rate of benefit abatement. He estimated that a $\$ 1000$ increase in the annual income guarantee would reduce the average annual work activity of female heads by 120 hours. In a similar study, and using the same data source, Moffitt (1980) estimated a response of 90 less hours worked, but found a very weak and statistically insignificant impact from the benefit abatement rate. ${ }^{2}$ Danziger et al. (1981) point to methodological weaknesses in both these later studies, and argue that neither of the analyses can be regarded as definitive. The only consensus on the effects of AFDC provision on female labour supply, is that higher levels of income guarantee reduce work activity by some amount.

Blau and Robins (1986a) examined the impact of AFDC benefits, food stamp benefits and general assistance benefits on the labour supply of men, youths and married women, as well as single woman household heads. Their study improved on the work of Hausman (1981) and Moffit (1980) because it utilised continuous work histories, from the newly established Employment Opportunities Pilot Project (EOPP), rather than the discrete annual changes in labour market status provided by PSID data. Calculating the differences in rates of transition from employment to unemployment, unemployment to employment, and to and from the labour force and employment or unemployment,

disincentive effects were held to exist if differences in transition rates between welfare

2 Moffitt's (1980) paper was unpublished. The other studies are reviewed in Danziger $e$ al. (1981). recipients and non-welfare recipients implied a reduction in the rate of employment, an increase in the rate of unemployment, or a decrease in the labour force participation rate for welfare recipients. Significant differences in transition rates for each group were found in almost all cases. The greatest differentials were for single woman household heads. Work disincentive effects were found to be associated only with a differential in the duration of unemployment and a lower rate of transition from unemployment employment. There was no significant difference in the propensity to enter spells of unemployment and the difference in the rate of transition from unemplits participation was not consistent with the operation of disincentive effects-unt to nonwelfare recipients were less likely to with wemployments labour force when faced with unemployment than unemployed non-recipients. Blau and Robins found that, while income support reduced work activity of recipients through extended duration of unemployment, there was some increased participation.

A suggested alternative to income support such as AFDC is a negative income tax (NIT). Instead of demanding taxes and then redistributing income through benefits, this operates by making direct cash payments to those who earn below a critical income threshold (New Zealand's Guaranteed Minimum Family Income is of this type). Whilst switching from AFDC may reduce the high effective tax rate (from benefit abatement as well as income tax) on the very poor, NIT payments may require an increase in the tax rate for other workers. Concern about possible work disincentive effects from the income taxes led to an unprecedented form of economic research. Between 1968 and 1978 the United States Federal Government sponsored four large scale experiments. In one group of low income families acted as a control and remained eligible for welfare, while similar individuals in a second group were given different income support levels but the same effective tax rate of support removal, or the same support levels but different tax rates. The overall effect of changes in incentives was found to be relatively small. Married men in the experiments reduced their hours of work by between 1 and 7 pmant. For married women the change was from a smaller base and the labour supply different. were large with reductions of between 17 percent and 31 percent. The impact of in effective tax rates, imposed by abatement of the NIT paym was limited, while the was limited, while the impact of the level of NIT support was more substantial (Whiteford, 1980). From these experiments, Betson et al. (1982) predict that the labour supply response to replacing the existing system with a NIT system would be a 0.4 to 0.8 percent increase in work activity, which is very small in relation to total labour supply. They conclude that economic efficiency in terms of labour supply should not weigh heavily in the choice of tax transfer systems.

Other results of interest from the NIT experiments include the findings that search time when unemployed increased under NIT support, and in one experiment area (Indiana), that the birth weight of babies born to NIT families was significantly higher than those born in the control group. In Seattle, providing women with an income guarantee independent of their husbands led to an increase in the break-up of families (Stiglitz 1986 p.499). Solo female heads of families were only studied in one of the experiments and were found to reduce their hours worked by between 2 and 12 percent, much less than the 17 to 31 percent reduction in hours worked by married women. Results of the NIT experiments should be used with caution, however. Stiglitz (1986) notes that the behaviour of individuals may change if they are subjects of experiments, and that sample selection may have been biased with participation in the experiments being voluntary only. In addition, responses to short-term changes may be different from reactions to permanent changes. Institutional structures, such as the availability of part-time work and the length of the working week, which condition labour supply responses, would also take time to adjust to changes in policy.

It would appear then that while disincentives may be inherent in income support systems, men do not generally act on them. Women do, but the impact of their response on total labour supply is small. 
(b) Indications from New Zealand

The only statistical testing of the relationship between income support provisions and labour supply in New Zealand is a study by Ross (1987) who found that, for married women, the probability of participation, but not the number of hours worked, is sensitive to the existence and level of household transfer income. Despite the lack of statistical testing there is much empirical work available, concerned mainly with the effects of income support for female solo parents. The proportion of solo parents in receipt of the Widows Benefit and Domestic Purposes Benefit (DPB) in New Zealand has risen from 58 percent in 1976 to 71 percent in 1984 , while the number of solo parent families has increased markedly.

There is a fear that the existence and level of support provided by the DPB in New Zealand has contributed to rising rates of marital breakdown and growing numbers of single women keeping their children, and that this has, in turn, had implications for women's labour supply. Wylie (1980), however, notes that the tendency for single mothers to keep their children predates the introduction of the statutory DPB by about five years. Further, the DPB is not financially attractive to married women. Beneficiary families have depressed standards of living in comparison to two parent families. families have depressed standards of living in comparison to two parent families. Introduction of the De

Dominick et al. (1988) found no evidence of a narrowing of the difference between wages and benefits to account for the decrease in the rate of employment of solo parents. the DPB with the average-ordinary-time female wage which is probably not representative of the wage attainable by DPB recipients. Their finding was that a stricter benefit income test in 1984 was the main cause of the reduced employment rate. Despite relaxation of the allowed earnings disregard in 1978, failure to index for inflation has reduced the real value of allowed earnings. They also find a relationship between the age of the youngest child and a solo mother's employment and argue that opportunity, provided by reasonable access to childcare, is as important, if not more important than financial incentives in determining the labour supply behaviour of solo mothers. Indeed Shipley (1982), who interviewed a small sample of female DPB recipients, noted two main preferences among the women. They wanted either (1) a part-time job which would not affect their benefit, or, (2) a full-time job well enough paid to cope with the extra costs such as childcare incurred in working full-time. Wylie (1980) interviewed female solo parents who were not DPB recipients but worked to support themselves and their families. For these women, access to suitable and affordable childcare was their biggest difficulty. Most were only able to work because and affordable childcare was their biggest difficulty. Most were only able to work because
friends and relatives would provide childcare at little cost. In Ross's (1987) study of the determinants of married women's labour supply the existence of pre-school children, and to a lesser extent primary school aged children, were the key explanatory variables. The leve of transfer income was less important.

The earnings capacity of women is also important in determining their labour supply behaviour. Dominick et al. (1988) suggest that work experience, skills and qualifications
have a significant impact on the rate of movement off the DPB into employment. have a significant impact on the rate of movement off the DPB into employment.
Shipley (1982) noted that most of her respondents could find no work, or only work that Shipley (1982) noted that most of her respondents could find no work, or only work that
would not support them better than the DPB. There is, perhaps, a case for arguing that would not support them better than the DPB. There is, perhaps, a case for arguing that unemployment, the DPB is more financially attractive than the Unemployment Benefit some proportion of DPB recipients may represent hidden unemployed workers. Causality, however, cannot be extended any further than this. Under the Australian system, which is however, cannot be extended any further than this. Under the Australian system, which is
reasonably similar to that operating in New Zealand, there is no evidence of a causal link reasonably similar to that operating in New Zealand, there is no evidence of a causal link
between rising unemployment and the increasing rate of ex-nuptial births, or that the availability of the Supporting Parent's Benefit influences the decision of teenagers to become pregnant (SSR Issues Paper No.3). Pregnancies were unplanned and the decision to mother the child generally reflected the lack of alternative social and economic options for teenage girls.

(c) Family income support and labour supply: a summary

There is no evidence that family income support has a discernable adverse impact on the labour supply of men. It would appear that the labour supply of married women and solo mothers is more sensitive to the level and terms of provision, but their response very small in terms of total work activity. There is no consensus on the effect of the rate of removal of income support on labour supply.

Empirical observation in New Zealand suggests no relationship between women's labour supply and the level of the DPB, although there is some indication that the smal size of the earnings disregard has a negative effect on part-time work activity. Increased usage of the DPB reflects social change which has contributed to the growth in numbers of needy families, and growing unemployment, in the face of which the DPB is the mos attractive income support alternative. The propensity for unemployed solo parents to claim the DPB instead of the Unemployment Benefit has no impact on work activity, although it may reduce participation, and reduces the measured incidence of unemployment.

\section{Conclusion}

This review of empirical findings on the labour supply effects of social security provision finds much continuing empirical debate. There is no consistent evidence that the level of unemployment benefits relative to wages has an influence on the probability of being unemployed or on the rate of unemployment. It is generally agreed that there is some impact on the duration of unemployment but there is little consensus on the length of extended duration. The significance of the effect, in terms of total labour supply, would appear trivial. Extended duration does not necessarily correspond with a higher rate of unemployment - where it facilitates a more extensive job search or retraining, unemployment in the long run may be reduced. Limiting the duration of benefit entitlement has an impact on the length of unemployment spells, but this may be more at the expense of participation in the labour force (and serve to disguise the true level of unemployment), than actual work activity.

The labour force participation and work activity of prime age men is least sensitive to benefit provision. Teenage men are the most sensitive to the level of benefits and the duration of eligibility. It would appear that the labour supply of women, but not men, is sensitive to the level of family income support. Again, in terms of total work activity, the response is trivial. The response to the rate of income support withdrawal is not certain. Since the empirical link between disincentives in social security programs and labour supply is not strong, it does not follow that reduced disincentives to work will have a substantial effect on labour supply. Indeed financial considerations are but one element in decisions about how much labour to supply. The supposition that individuals calculate the financial incentives and disincentives they face and govern their behaviour by them is simplistic. Non-financial rewards from working such as stimulation, security, companionship and status are as, if not more important, and other economic, institutional, social and cultural factors very much bind any individual's decision set.

We perhaps need to step back and question the reason for the concern over the effects of social security provision on labour supply and the rationale for benefit reform. If the rationale is to ensure efficient and full use of labour power in the economy, then there is no substantial evidence to suggest a need for concern over the impact of benefits on labour supply. If, on the other hand, labour supply is the real issue of concern then there are other, more effective ways to alter labour supply behaviour. Addressing the demand for labour in the economy and opportunities for workers, particularly married women, to 
supply their labour is one way. Easing constraints imposed by the costs of occupationa and geographical mobility and the cost and availability of childcare are others. If concern with labour supply is a means to an end - a means to reduce the number of benefit claimants and reduce the fiscal burden of rising unemployment and the rising incidence of low pay, then reducing benefits relative to wages will be largely ineffective.

If, however, the proposed benefit cuts are a means to cut costs in themselves, and not intended to have any impact on the work activity of income support recipients or the rate or duration of unemployment, then they will be effective. It must be recognised that the greatest impact of cuts will be on the consumption levels of beneficiaries, not their labour supply behaviour. In the absence of satisfactory state provision, the burden of support would fall on family units or private charitable sources. The level and terms of support would fall on family units or private charitable sources. The level and terms of support
would not be guaranteed and ethically (and politically) undesirable forms of dependence in society would be reinstated or accentuated. If the rationale for reform is cost reduction then proposed changes should be debated in this context.

In this paper we have shown that the assertion that disincentives in social security programs have substantial effects on actual labour supply appears to be an "economic myth". ${ }^{3}$ Accordingly, attempts to reduce unemployment or poverty by cutting benefits or limiting their duration to reduce labour supply disincentives are largely mistaken, and it is misleading to present reforms that are essentially cost cutting measures as the solution to increasing welfare dependency.

\section{References}

Atkinson, A B (1987) Income maintenance and social insurance. In Auerbach, A J and Feldstein, M (eds) Handbook of public economics North Holland, Elsevier.

Atkinson, A B, Gomulka, J and Micklewright, J (1984) Unemployment Benefits, duration and incentives in Britain: how robust is the evidence? Journal of public economics 22:3-26.

Atkinson, A B and Micklewright, J (1985) Unemployment Benefits and unemployment duration London, London School of Economics and Political Science.

Barr, N and Hall, R (1981) The probability of dependence on public assistance Economica 4:109-123.

Barron, T and Mellow, W (1981) Unemployment Insurance: the recipients and its impact Southern economic journal 47(3):606-616.

Beenstock, M and associates (1987) Work welfare and taxation - a study of labour supply incentives in the UK London, Allen and Unwin.

Betson, D, Greenberg, D and Katsen, R (1982) A simulation analysis of the economic and distributional effects of alternative program structures: the negative income tax versus the credit income tax. In Garfinkel, I (ed) Income-tested transfer programs : the case for and against New York, Academic.
Blau, D and Robins, P (1986a) Labour supply response to welfare programs: a dynamic analysis Journal of labour economics 4(1):82-104.

Blau, D and Robins, P (1986b) Job search wage offers and Unemployment Insurance Journal of public economics 29(2):173-198.

Braae, G P (1978) The effects of Unemployment Benefits on the rate of unemployment in New Zealand. In Grubel, H G and Walker, M A (eds) Unemployment Insurance: global evidence of its effects on unemployment Vancouver, The Fraser Institute.

Brosnan, P (1987) Unemployment and the Invalids Benefit New Zealand population review 13(1):71-79.

Burgess, P and Kingston, J (1981) UI benefit's effects on compensated unemployment Industrial relations 20:258-270.

Capen, M, Cohn, E and Elbon, R (1985) Labour supply effects of Unemployment Insurance benefits Applied economics 17:73-85.

Danziger, S, Haveman, R and Plotnick, R (1981) How income transfer programs affect work savings and the income distribution: a critical review Journal of economic literature 19:975-1028.

Dominick, C H, Rochford, M W and Robb, M J (1988) Solo parents benefits and employment Wellington, Department of Social Welfare (Research Series 5).

Freeman, R B (1979) Labour Economics Englewood Cliffs, Prentice-Hall.

Garfinkel, I and Orr, L (1974) Welfare policy and employment rate of AFDC mothers National tax journal 27(2):275-284.

Gregory, R A and Paterson, P R (1983) Impact of Unemployment Benefit payments on the level and composition of unemployment in Australia. In Trewin, D (ed) Statistics in the labour market: their role in planning and policy formulation New York, Marcel Dekker Inc.

Grubel, H and Maki, D (1976) The effects of Unemployment Benefits on US unemployment rates Weltwirtschaftliches archiv 112:274-299.

Gruen, F (1982) The welfare expenditure debate: economic myths of the Left and the Right Economic record 58:207-223.

Hamermesh, D (1977) Jobless pay and the economy Baltimore, John Hopkins University Press.

Hamermesh, D(1979) Entitlement effects, Unemployment Insurance and employment decisions Economic Inquiry 17:317-332.

Hamermesh, D (1980) UI and labour supply International economic review 21:517-527

Harrison, A J and Hart, R A (1983) Unemployment Benefits and labour supply: a note Welwirtschaftliches archiv 119:169-172. 
Hausman, J (1981) Labour supply. In Aaron H J and Pechman J (eds) How taxes affect economic behaviour Washington DC, Brookings Institution.

Hemming, R (1984) Poverty and incentives: the economics of social security Oxford, Oxford University Press.

Hicks, J R L (1984) Unemployment: some aspects of the New Zealand experience 1960$81 \mathrm{PhD}$ thesis, Massey University.

Hillier, B (1985) Unemployment Benefits and labour supply: a note on the theoretical foundations Weltwirtschaftliches archiv 121(2):315-20.

Household Labour Force Survey Department of Statistics, Wellington.

Hunter, L C et al. (1986) Information gaps in the local labour market Glasgow, Department of Social and Economic Research, University of Glasgow.

Hyslop, D (1987) The duration of Unemployment Benefit in New Zealand 1981-85 BCA (Hons) thesis, Victoria University of Wellington.

Layard, R (1986) How to beat unemployment Oxford, Oxford University Press.

Layard, R and Nickell, S (1986) Unemployment in Britain Economica 53(210) (S):s121-169.

Levy, F (1979) The labour supply of female household heads or AFDC work incentives dont work too well Journal of human resources 14(1):76-97.

Louis, R, Burgess, P and Kingston, J (1986) Reported vs actual job search by Unemployment Insurance claimants Journal of human resources 21(1):92-117.

Masters, S and Garfinkel, I (1977) Estimating the labour supply effects of income maintenance alternatives New York, Academic Press.

Minford, P (1983) Unemployment: cause and cure London, Martin Robertson.

Moffit, R (1980) An economic model of welfare stigma unpublished paper, New Brunswick, Rutgers University.

Moffit, R (1985) Unemployment Insurance and the distribution of unemployment spells Journal of econometrics 28(1):85-101.

Narandranathan, W, Nickell, S and Stern, J (1985) Unemployment benefits revisited The economic journal 95:307-329.

New Zealand Business Roundtable (1988) Unemployment income support in New Zealand: options for policy reform Wellington.

Nickell, S (1987) Estimating the probability of leaving unemployment Economica 47:1249-1266.

Nickel, S (1984) A review of "Unemployment: cause and cure" by Patrick Minford et al. The economic journal 94:946-953.
Ross, R T (1987) Disaggregate labour supply functions for married women in New Zealand New Zealand economic papers 21:41-56.

Osberg, L, Apostle, R and Clairmont, D (1986) The incidence and duration of individual unemployment: supply side or demand side? Cambridge journal of economics 10:13-33.

Saks, D (1975) Public assistance for mothers in an urban labour market Princeton NJ, Industrial Relations Section Princeton University.

Shipley, S M (1982) Women's employment and unemployment: a research report Palmerston North, Massey University Department of Sociology and the Society for Research on Women in New Zealand Inc.

Social Security Review (1987) Bringing up children alone: policies for solo parents Issues Paper No 3, Canberra.

Social Security Review (1988) I ncome support for the unemployed in Australia: towards a more active system Issues Paper No 4, Canberra.

Solon, G (1979) Labour supply effects of extended Unemployment Benefits Journal of human resources 14(2):247-55.

Stricker, P and Sheehan, P (1981) Hidden unemployment : the Australian experience Melbourne, Institute of Applied Economic and Social Research, University of Melbourne.

Whiteford, P (1980) Work incentives experiments in the USA and Canada Social security journal June:27-44.

Williams, R (1975) Public assistance and work effort Princeton NJ, Industrial Relations Section, Princeton University.

Wylie, C R (1980) Factors affecting the participation in the workforce of female heads of one parent families Wellington, Department of Social Welfare. 


\section{RELATIONS INDUSTRIELLES INDUSTRIAL RELATIONS}

Revue trimestrielle bilingue publiée par le Département des relations industrielles de I'Université Laval, Québec, Canada - A quarterly bilingual Journal published by the Département des relations industrielles, Université Laval, Québec, Canada. Directeur -Editor: Gérard Dion.

\section{SOMMAIRE - CONTENTS}

volume 43 , numéro 4,1988

Bureautique et organisation du travail de secrétariat dans la fonction publique québécoise

Claudine AUDET et Alain VINET

New Technologies and the Organization of Secretarial Work in the Québec Civil Service

Estimates of Unionism and Collective Bargaining Coverage in Canada Pradeep KUMAR

Travailleurs syndiqués et travailleurs couverts par conventions collectives au Canada

Towards an Historical Understanding of Industrial Relations Theory in Canada Gregor MURRAY and Antony GILES

La théorie des relations industrielles au Canada: une approche historique

Les nouvelles lois du travail et l'activité de grève Robert LACROIX et André LESPÉRANCE

New Labor Laws and Strike Activity

High Technology Industries and Non-Union Establishments in Britain P.B. BEAUMONT and R.I.D. HARRIS

Industries de haute technologie et entreprises non syndiquées en Grande-Bretagne

Unions, Politics and Law in Canada Michael MAC NEIL

Syndicats, politique et législation au Canada

Socio-Technical Systems: Conceptual and Implementation Problems Bob MATON

Problèmes conceptuels et de mise en oeuvre des systèmes socio-techniques

The Exclusive Remedy Provision in Canadian Worker Compensation Law:

The Need for Legislative Reform

Leigh WEST

L'exclusion de la responsabilité des employeurs dans les accidents du travail

DROIT DU TRAVAIL

L'amnistie des fautes disciplinaires Claude D'AOUST

Préavis de licenciement ou son équivalent Fernand MORIN

Décisions rendues par le Conseil canadien des relations du travail Véronique L. MARLEAU

Changements dans les législations du travail au Canada Michel GAUVIN et Geoffrey BRENNAN

Recensions - Book Reviews

Publications récentes - Recent Publications

Livres reçus - Books Received

Liste des appréciateurs - 1988 - List of Referees

INDEX, vol. 43,1988

Abonnements annuels - Annual Subcriptions - Institutions: \$48.00; Individus - Individuals: Canada, \$24.00; Étranger - Foreign: $\$ 26.00$. Le numéro - Single Issue $\$ 7.00$ - Les Presses de I'Université Laval, C.P. 2477, Québec, Qué. Canada, G1K 7R4. 